Article

\title{
Digestion of Alumina from Non-Magnetic Material Obtained from Magnetic Separation of Reduced Iron-Rich Diasporic Bauxite with Sodium Salts
}

\author{
Guanghui Li, Jun Luo *, Tao Jiang *, Zhuoxuan Li, Zhiwei Peng and Yuanbo Zhang \\ School of Minerals Processing \& Bioengineering, Central South University, Changsha 410083, China; \\ liguangh@csu.edu.cn (G.L.); lzx0117@csu.edu.cn (Z.L.); zwpeng@csu.edu.cn (Z.P.); zybcsu@126.com (Y.Z.) \\ * Correspondence: luojun2013@csu.edu.cn (J.L.); jiangtao@csu.edu.cn (T.J.); \\ Tel.: +86-731-888-305-42 (J.L.); +86-731-888-792-60 (T.J.)
}

Academic Editor: Hugo F. Lopez

Received: 8 October 2016; Accepted: 17 November 2016; Published: 23 November 2016

\begin{abstract}
Recovery of iron from iron-rich diasporic bauxite ore via reductive roasting followed by magnetic separation has been explored recently. However, the efficiency of alumina extraction in the non-magnetic materials is absent. In this paper, a further study on the digestion of alumina by the Bayer process from non-magnetic material obtained after magnetic separation of reduced iron-rich diasporic bauxite with sodium salts was investigated. The results indicate that the addition of sodium salts can destroy the original occurrences of iron-, aluminum- and silicon-containing minerals of bauxite ore during reductive roasting. Meanwhile, the reactions of sodium salts with complex aluminum- and silicon-bearing phases generate diaoyudaoite and sodium aluminosilicate. The separation of iron via reductive roasting of bauxite ore with sodium salts followed by magnetic separation improves alumina digestion in the Bayer process. When the alumina-bearing material in bauxite ore is converted into non-magnetic material, the digestion temperature decreases significantly from $280{ }^{\circ} \mathrm{C}$ to $240{ }^{\circ} \mathrm{C}$ with a nearly $99 \%$ relative digestion ratio of alumina.
\end{abstract}

Keywords: diasporic bauxite; alumina; digestion; sodium salts; Bayer process

\section{Introduction}

Bauxite ore is the main raw material used in alumina production. Almost $90 \%$ of world's alumina production is from bauxite using the Bayer process [1,2]. The bauxite ore with high alumina content and a high mass ratio of alumina to silica (A/S ratio) is preferred in the alumina industry. Iron-rich diasporic bauxite ore, usually containing over 15 wt. \% iron oxide [3-5], has huge reserves in Australia, Guinea, Brazil, Vietnam, Laos and China [6], but has not yet been exploited to its full potential.

The diasporic bauxite ore requires a high digestion temperature and strong caustic soda solutions during the Bayer process. The digestion temperature of diaspore is about $260-280{ }^{\circ} \mathrm{C}$, much higher than those of boehmite (about $230^{\circ} \mathrm{C}$ ) and gibbsite (about $140{ }^{\circ} \mathrm{C}$ ). These features lead to inefficient and costly alumina production from diasporic bauxite using this process. Furthermore, the high iron content in bauxite ore is unfavorable for alumina digestion. The large amount of iron oxide in the red mud also poses a potential environmental risk [7-10]. It is thus more appropriate to separate iron first from the iron-rich diasporic bauxite for the Bayer process.

Many studies have been conducted to separate iron constituents from the iron-rich bauxite by using physical methods [3,11], pyro- and hydro-metallurgical processes [5,12-14], and bio-leaching methods $[4,15]$. Generally, it is difficult to achieve the sufficient separation of iron due to the complex occurrences and associations of disseminated iron-, aluminum-, and silicon-bearing minerals. The physical methods depend on the specific chemical composition of minerals and are merely 
suitable for processing the bauxite ores with simple mineral occurrences. Conversely, pyro- and hydro-metallurgical processes appear to be useful for the treatment of complex bauxite ores. Pickles et al. separated the magnetite from reduced bauxite by magnetic separation after carbothermal reduction which transformed hematite to magnetite. Fifty-eight percent of iron was removed in the non-magnetic material with an alumina recovery of $85 \%$ [5].

The recent studies indicated that metallization reductive roasting followed by magnetic separation is efficient for separating and recovering iron from refractory iron-containing ores, and sodium salts (e.g., sodium carbonate and sodium sulfate) are the appropriate additives for improving the iron separation in the process [16-21]. A recent study by the authors [22] has confirmed that $92.51 \%$ of iron was separated and a powdered direct reduction iron (DRI) with $88.17 \%$ total iron content (TFe) was obtained under the optimal conditions. Meanwhile, the alumina, silica, and other valuable components such as titanium and rare earth in non-magnetic material could be selectively recycled. As the major component, the extraction of alumina is important and it is also conducive to further enriching and recovering titanium and rare earth. Several authors proposed that the alumina in the Bayer red mud can be recovered via alkali roasting followed by water leaching. During the alkali roasting, the reaction of sodium aluminosilicate hydrate in red mud with $\mathrm{Na}_{2} \mathrm{CO}_{3}$ forms $\mathrm{NaAlO}_{2}$, due to the conversion of $\mathrm{SiO}_{2}$ into $\mathrm{CaSiO}_{3}$ via the addition of $\mathrm{CaO}$-bearing substances [23-25]. However, during the reductive roasting of high aluminum and silicon ores with sodium salts, but without $\mathrm{CaO}$, the $\mathrm{Al}_{2} \mathrm{O}_{3}$ and $\mathrm{SiO}_{2}$ react with $\mathrm{Na}_{2} \mathrm{CO}_{3}$ and form other sodium aluminosilicates such as $\mathrm{Na}_{2} \mathrm{O} \cdot \mathrm{Al}_{2} \mathrm{O}_{3} \cdot 6 \mathrm{SiO}_{2}$, $\mathrm{Na}_{2} \mathrm{O} \cdot \mathrm{Al}_{2} \mathrm{O}_{3} \cdot 4 \mathrm{SiO}_{2}$ and $\mathrm{Na}_{1.55} \mathrm{Al}_{1.55} \mathrm{Si}_{0.45} \mathrm{O}_{4}$, which are not dissolved in water [9,18]. Moreover, there is lack of research on the alumina extraction from these materials with various sodium aluminates and aluminosilicates, and the effectiveness of alumina extraction has been unclear heretofore.

In the present study, the digestion of alumina from non-magnetic material via the Bayer process was investigated. For comparison, the direct digestion of alumina from iron-rich diasporic bauxite ore was also considered by using the Bayer process. The superiority of alumina digestion from non-magnetic material was discussed intensively.

\section{Materials and Methods}

\subsection{Materials}

Non-magnetic material used in this study was prepared via reductive roasting of iron-rich diasporic bauxite with sodium salts followed by magnetic separation.

Iron-rich diasporic bauxite was taken from the southwest Yunnan, China. Its chemical composition is shown in Table 1. The total iron content was $17.43 \%$ and much higher than that of the conventional bauxite ore. The contents of alumina and silica were $41.83 \%$ and $15.10 \%$, respectively.

Table 1. Chemical composition of iron-rich bauxite ore and non-magnetic material/wt. \%.

\begin{tabular}{ccccccccc}
\hline Composition & $\mathbf{F e}_{\text {total }}$ & $\mathrm{Al}_{\mathbf{2}} \mathbf{O}_{\mathbf{3}}$ & $\mathrm{SiO}_{\mathbf{2}}$ & $\mathrm{TiO}_{\mathbf{2}}$ & $\mathbf{N a}_{\mathbf{2}} \mathbf{O}$ & $\mathbf{C a O}$ & $\mathbf{M g O}$ & LOI $^{\mathbf{1}}$ \\
\hline Bauxite ore & 17.43 & 41.83 & 15.10 & 3.81 & 0.05 & 0.09 & 0.08 & 13.10 \\
Non-magnetic material & 4.55 & 43.20 & 18.11 & 4.25 & 17.58 & 0.11 & 0.09 & 10.03 \\
\hline \multicolumn{8}{c}{ LOI: Loss on ignition. }
\end{tabular}

The chemical composition of non-magnetic material was also determined. The result in Table 1 demonstrates that the contents of $\mathrm{Al}_{2} \mathrm{O}_{3}, \mathrm{SiO}_{2}$ and $\mathrm{TiO}_{2}$ in non-magnetic material are higher than those of bauxite ore after separating of iron. The addition of sodium salts caused increase of the $\mathrm{Na}_{2} \mathrm{O}$ content from $0.05 \%$ to $17.58 \%$ and decrease of the total iron content to $4.55 \%$.

\subsection{Methods}

The ground bauxite ore mixed with sodium salts including $35 \mathrm{wt}$. \% sodium carbonate, $10 \mathrm{wt}$. \% sodium sulfate and $2 \mathrm{wt}$. \% borax was briquetted into cylinders. The stainless tube (dimensions 
of $\Phi 50 \mathrm{~mm} \times 200 \mathrm{~mm}$ ) loaded the dried briquettes with size of $\Phi 10 \mathrm{~mm} \times 10 \mathrm{~mm}$ was filled with lignite as reductant and placed in the vertical resistance furnace to perform the reductive roasting at $1050{ }^{\circ} \mathrm{C}$ for $60 \mathrm{~min}$. Then the cooled briquettes were crushed and ground in a ball mill to preparation of pulp with $98 \mathrm{wt}$. \% particles passing $-0.074 \mathrm{~mm}$. The non-magnetic material was obtained after magnetic separation of pulp in a XCGS-73 Davis magnetic tube (Changsha, China) with magnetic field intensity of $1000 \mathrm{Gs}$. The procedure for reduction and magnetic separation of bauxite ore was detailed described in the literature [22]. Under the optimized conditions, $83.6 \mathrm{wt}$. \% non-magnetic fraction with $86.3 \mathrm{wt}$. \% alumina occupation was obtained for the followed alumina digestion.

The digestion process was performed in a self-designed reactor equipped with four $150 \mathrm{~mL}$ stainless steel pots that rotate in a molten salt bath (Figure 1). The molten salts included sodium nitrate, potassium nitrate and sodium nitrite. Synthetic pregnant liquor was prepared by dissolving sodium hydroxide and aluminum hydroxide in deionized water. The pregnant liquor and the non-magnetic material were transferred into the pots before digestion in which the sealed pots were immersed in the bath with the specified temperature. The reactor was rotated at $30 \mathrm{rpm}$. After digestion, the sealed pots were taken out and cooled to $80-90^{\circ} \mathrm{C}$ with the cooling rate of $20^{\circ} \mathrm{C} / \mathrm{min}$, then the suspension in pots was immediately separated and the residue cake was washed using hot water (about $80-90^{\circ} \mathrm{C}$ ). The dried residue was collected for determination of chemical composition.

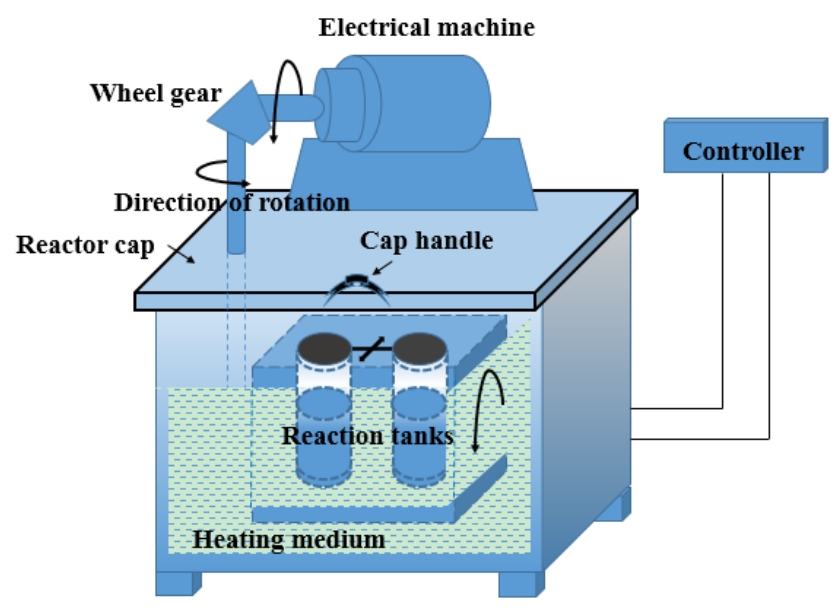

Figure 1. Schematic of the reactor equipment.

The actual and relative digestion ratios of alumina, and the yield of residue are used as the evaluation indexes. Their calculations are given as follows:

$$
\begin{gathered}
\eta_{1}=\frac{A_{1}-S_{1}}{A_{1}} \times 100 \%=\left[1-\left(\frac{1}{A_{1} / S_{1}}\right)\right] \times 100 \% \\
\eta_{2}=\frac{A_{1}-A_{2} \times Y}{A_{1}} \times 100 \% \\
\eta_{3}=\frac{\eta_{2}}{\eta_{1}} \times 100 \%
\end{gathered}
$$

where $\eta_{1}$ is the theoretical digestion ratio of alumina, its value is the constant for a specific feed as A/S ratio is fixed; $\eta_{2}$ is the actual digestion ratio of alumina; $\eta_{3}$ is the relative digestion ratio of alumina. $A_{1}$ and $A_{2}$ represent the alumina contents in the feed and red mud, respectively, wt. \%; $S_{1}$ and $S_{2}$ represent the $\mathrm{SiO}_{2}$ contents in the feed and red mud, respectively, wt. \%, and $Y$ is the yield of red mud, \%. 


\section{Results and Discussion}

\subsection{Digestion Alumina from Non-Magnetic Material}

\subsubsection{Effects of Caustic Soda Concentration and Caustic Ratio}

The caustic soda concentration and caustic ratio in pregnant liquor strongly influence the digestion of alumina in the Bayer process. Generally, a high caustic ratio and caustic soda concentration are beneficial to the alumina digestion, because of the unsaturation of $\mathrm{Al}_{2} \mathrm{O}_{3}$ in the pregnant liquor. The effect of the caustic soda concentration on the alumina digestion in the non-magnetic material was verified, and the results are shown in Figure 2. The other conditions were kept at the digestion temperature of $240{ }^{\circ} \mathrm{C}$, the digestion time of $60 \mathrm{~min}$, the caustic ratio of 3.0 in the pregnant liquor, and the liquid-to-solid ratio of $4.0 \mathrm{~mL} / \mathrm{g}$. The results indicate that the alumina digestion from the non-magnetic material increases first and then decreases with the increasing caustic soda concentration. The digestion of alumina reaches a maximum at the caustic soda concentration of $260 \mathrm{~g} / \mathrm{L}$. Note that there is a small difference in alumina digestion when the caustic soda concentration varies between $240 \mathrm{~g} / \mathrm{L}$ and $260 \mathrm{~g} / \mathrm{L}$.

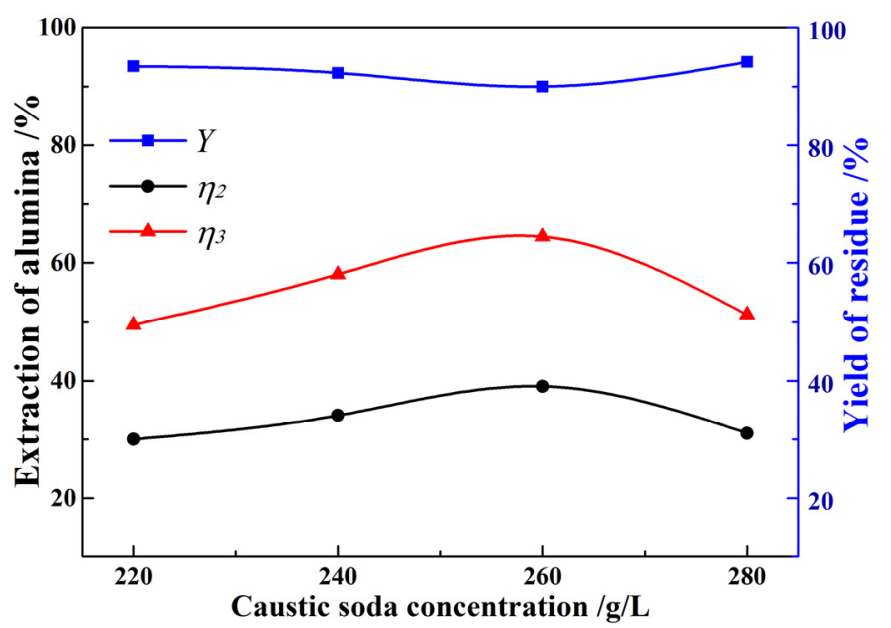

Figure 2. Effect of caustic soda concentration on the alumina digestion.

The effect of the caustic ratio on the alumina digestion was also examined. The conditions were a caustic soda concentration of $240 \mathrm{~g} / \mathrm{L}$ in the pregnant liquor, a digestion temperature of $240{ }^{\circ} \mathrm{C}$, a digestion time of $60 \mathrm{~min}$, and a liquid-to-solid ratio of $4.0 \mathrm{~mL} / \mathrm{g}$. As shown in Figure 3, increasing the caustic ratio has a favorable impact on the alumina digestion. The relative digestion ratio of alumina improves from $58.08 \%$ to $71.43 \%$ when the caustic ratio increases from 3.0 to 4.5 . Meanwhile, the yield of red mud decreases from $92.30 \%$ to $83.56 \%$. 


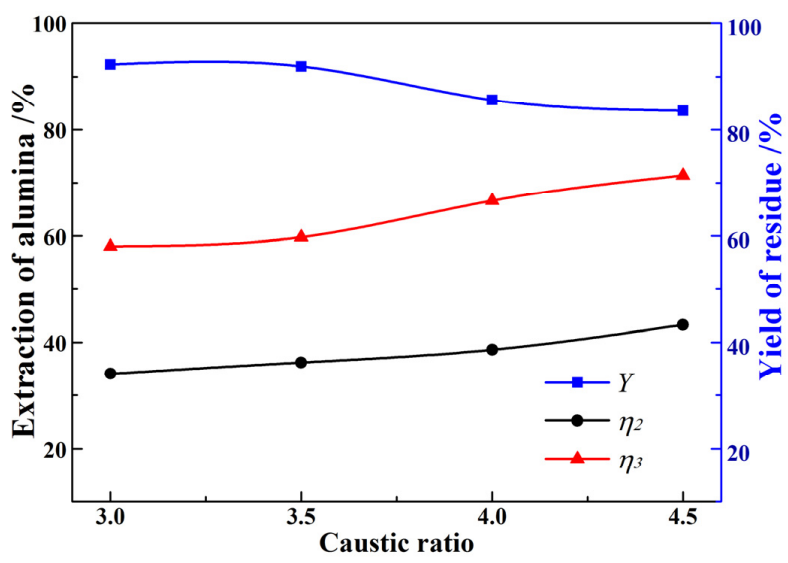

Figure 3. Effect of caustic ratio on the alumina digestion.

\subsubsection{Effect of Digestion Temperature}

The above results suggest that the alumina digestion is satisfactory at a low digestion temperature in spite of the high caustic soda concentration or caustic ratio. Hence the effect of the digestion temperature was further explored. The conditions were a digestion time of $60 \mathrm{~min}$, a caustic soda concentration of $240 \mathrm{~g} / \mathrm{L}$, with a caustic ratio of 4.0 in pregnant liquor, and a liquid-to-solid ratio of $4.0 \mathrm{~mL} / \mathrm{g}$.

As seen from Figure 4, the alumina digestion increases significantly when the temperature increases. Only $30.93 \%$ of alumina is digested from the non-magnetic material at $220{ }^{\circ} \mathrm{C}$, with the yield of red mud exceeding $92.6 \%$, indicating the precipitation of sodium aluminosilicates instead of the digestion of alumina during the digestion process. However, the relative digestion ratio of alumina increases from $53.35 \%$ to $94.72 \%$ when the temperature varies from $220{ }^{\circ} \mathrm{C}$ to $280{ }^{\circ} \mathrm{C}$. With the increasing digestion temperature, more alumina is dissolved in the pregnant liquor, and the yield of red mud reduces significantly. However, generally, it is impractical to use a too-high digestion temperature in the view of energy consumption and preparation.

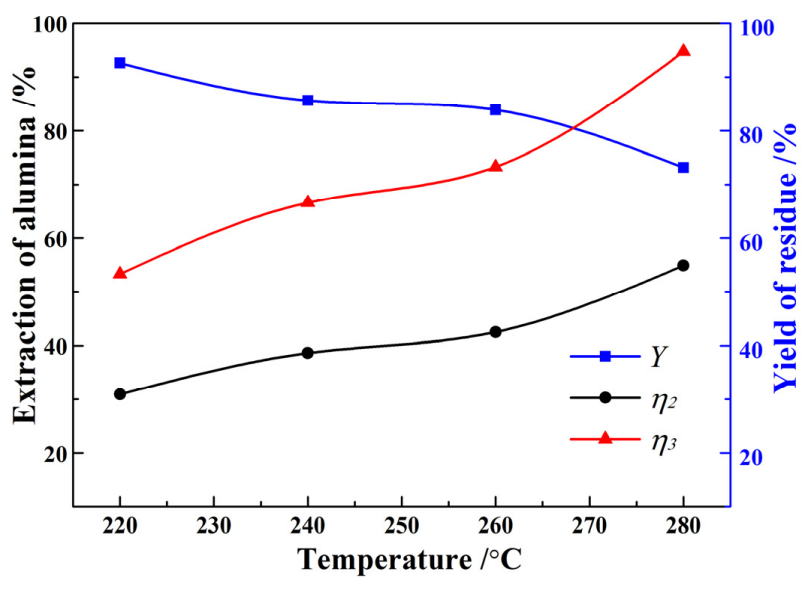

Figure 4. Effect of digestion temperature on the alumina digestion.

\subsubsection{Effect of Lime Addition}

Lime is widely applied in the Bayer process for improving the digestion efficiency. The effect of the addition of lime on the digestion of the non-magnetic material was investigated. The other experimental parameters were a digestion temperature of $240^{\circ} \mathrm{C}$, a digestion time of $60 \mathrm{~min}$, a caustic soda concentration of $240 \mathrm{~g} / \mathrm{L}$ with a caustic ratio of 3.0 in the pregnant liquor, and a liquid-to-solid ratio of $4.0 \mathrm{~mL} / \mathrm{g}$. 
The results presented in Figure 5 indicate that the digestion of alumina improves obviously with the increasing addition of lime. The relative digestion ratio of alumina reaches $99.58 \%$ with the red mud yield of $56.59 \%$ when the lime dosage is $4.0 \%$. Further increasing the lime dosage leads to a slight change in alumina digestion. Obviously, the addition of lime is beneficial to reducing the digestion temperature in the Bayer process. It is found that the digestion temperature is only $240{ }^{\circ} \mathrm{C}$ under the lime dosage of $4.0 \%$ when the alumina extraction is complete.

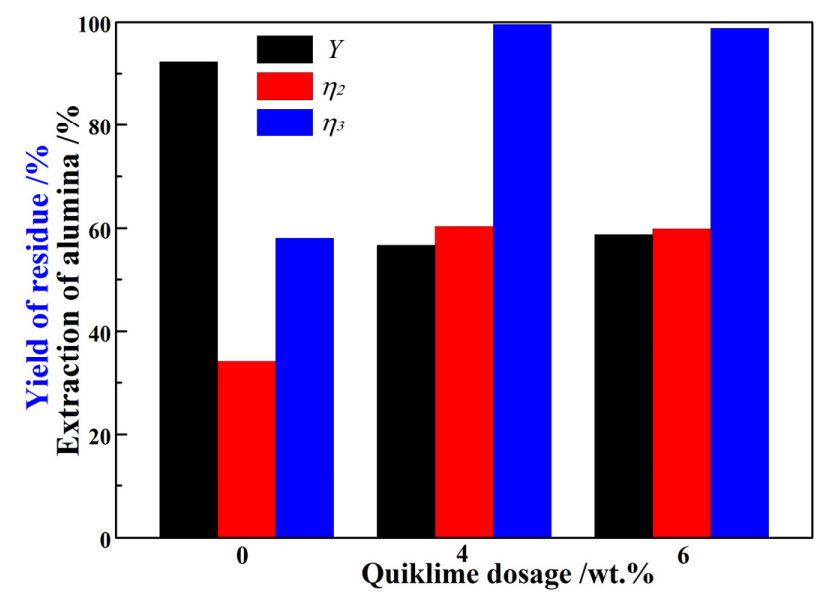

Figure 5. Effect of lime dosage on the alumina digestion.

\subsection{Mechanisms on Improvement of Alumina Digestion of Non-Magnetic Material}

\subsubsection{Digestion Characteristics Comparison between Iron-Rich Diasporic Bauxite and} Non-Magnetic Material

Table 2 compares alumina digestion from iron-rich diasporic bauxite and non-magnetic material. Obviously, it is feasible to digest the non-magnetic material at a lower temperature than that of iron-rich bauxite ore. Compared with bauxite ore, the digestion temperature of non-magnetic material decreases from $280{ }^{\circ} \mathrm{C}$ to $240{ }^{\circ} \mathrm{C}$ on the premise of a nearly $99 \%$ relative digestion ratio of alumina, with the simultaneous reduction of the caustic ratio from 4.0 to 3.0. Besides, due to the separation of iron, the yield of red mud reduces from $78.19 \%$ to $56.59 \%$. The results confirm that the digestion of alumina from the non-magnetic material is superior to that of the iron-rich bauxite ore.

Table 2. Comparison of the alumina digestion from iron-rich bauxite ore and non-magnetic material.

\begin{tabular}{cccc}
\hline Samples & Iron-Rich Bauxite Ore & Non-Magnetic Material \\
\hline Digestion temperature $/{ }^{\circ} \mathrm{C}$ & 240 & 280 & 240 \\
Digestion time/min & 60 & 60 & 60 \\
Caustic soda concentration/g/L & 240 & 240 & 240 \\
Caustic ratio & 4.0 & 4.0 & 3.0 \\
Lime dosage/wt. $\%$ & 4.0 & 4.0 & 4.0 \\
$\eta_{2} / \%$ & 13.09 & 63.10 & 60.38 \\
$\eta_{3} / \%$ & 20.48 & 98.75 & 99.58 \\
$Y / \%$ & 104.36 & 78.19 & 56.59 \\
\hline
\end{tabular}

\subsubsection{Improving Mechanisms of Alumina Digestion of Non-Magnetic Material}

According to Figure 6, the alumina in iron-rich bauxite ore occurs in the phases of diaspore $(\alpha-\mathrm{AlOOH})$, boehmite $(\gamma-\mathrm{AlOOH})$ and kaolinite $\left(\mathrm{Al}_{2} \mathrm{O}_{3} \cdot 2 \mathrm{SiO}_{2} \cdot 2 \mathrm{H}_{2} \mathrm{O}\right)($ Figure $6 \mathrm{~A})$. During the reductive roasting, the hematite is reduced to metallic iron (Equation (4)), and the alumina and silica, produced from the decomposition of diasporite (Equation (5)) [26], boehmite and kaolinite in the iron-rich bauxite 
ore, react with sodium salts and generate sodium aluminates and aluminosilicates $[18,27,28]$; in the case of sodium carbonate as the primary additive, the reactions are as seen in Equations (6) and (7). In the present system, the aluminum-bearing phases in the non-magnetic material transform into diaoyudaoite $\left(\mathrm{NaAl}_{11} \mathrm{O}_{17}\right)$ and sodium aluminosilicate $\left(\mathrm{Na}_{1.55}\left(\mathrm{Al}_{1.55} \mathrm{Si}_{1.45}\right) \mathrm{O}_{4}\right)$ (Figure 6B).

$$
\begin{gathered}
\mathrm{Fe}_{2} \mathrm{O}_{3}+3 \mathrm{CO} \rightarrow 2 \mathrm{Fe}+3 \mathrm{CO}_{2} \\
\mathrm{Al}_{2} \mathrm{O}_{3} \cdot 2 \mathrm{SiO}_{2} \cdot 2 \mathrm{H}_{2} \mathrm{O} \rightarrow \mathrm{Al}_{2} \mathrm{O}_{3}+2 \mathrm{SiO}_{2}+2 \mathrm{H}_{2} \mathrm{O} \\
x \mathrm{Na}_{2} \mathrm{CO}_{3}+y \mathrm{Al}_{2} \mathrm{O}_{3} \rightarrow 2 \mathrm{Na}_{x} \mathrm{Al}_{\mathrm{y}} \mathrm{O}_{(x+3 y)}+x \mathrm{CO}_{2} \\
x \mathrm{Na}_{2} \mathrm{CO}_{3}+y \mathrm{Al}_{2} \mathrm{O}_{3}+z \mathrm{SiO}_{2} \rightarrow x \mathrm{Na}_{2} \mathrm{O} \cdot y \mathrm{Al}_{2} \mathrm{O}_{3} \cdot z \mathrm{SiO}_{2}+x \mathrm{CO}_{2}
\end{gathered}
$$

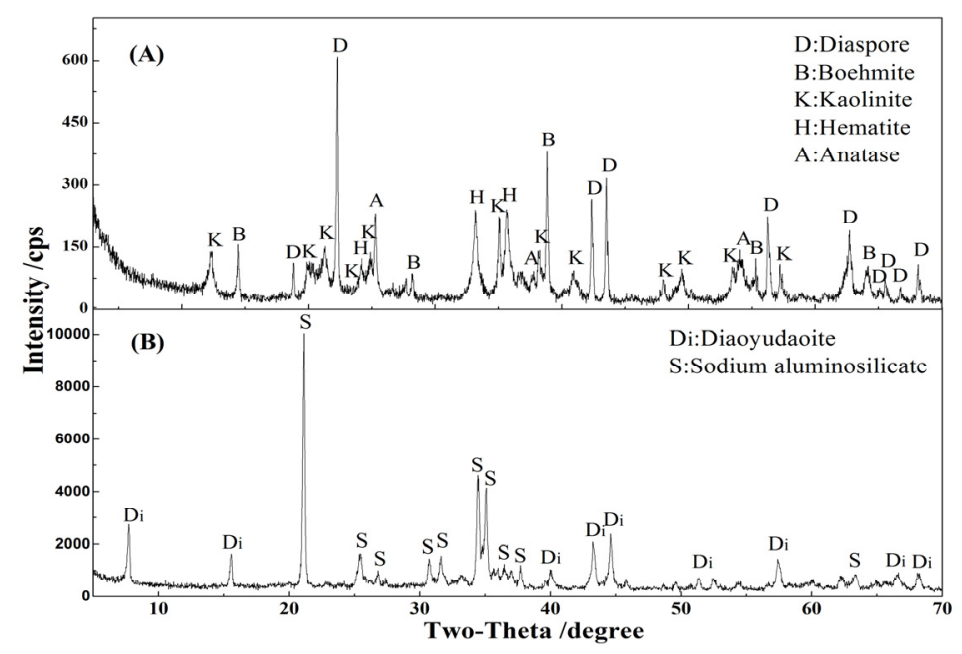

Figure 6. XRD patterns of iron-rich bauxite ore (A) and non-magnetic material (B).

Furthermore, it is observed from Figure 7A that the occurrences of hematite, kaolinite and diaspore in iron-rich bauxite ore are more complex. Especially, the main iron-bearing mineral, hematite, is surrounded by the matrix phases of diaspore and kaolinite. It is necessary to destroy the original structure of the minerals for extracting alumina. Figure 7B shows that the aggregation of metallic iron during reductive roasting. Due to the reduction of iron-bearing mineral, the structure of matrix minerals is destroyed, and the aluminum-bearing phases are independent.

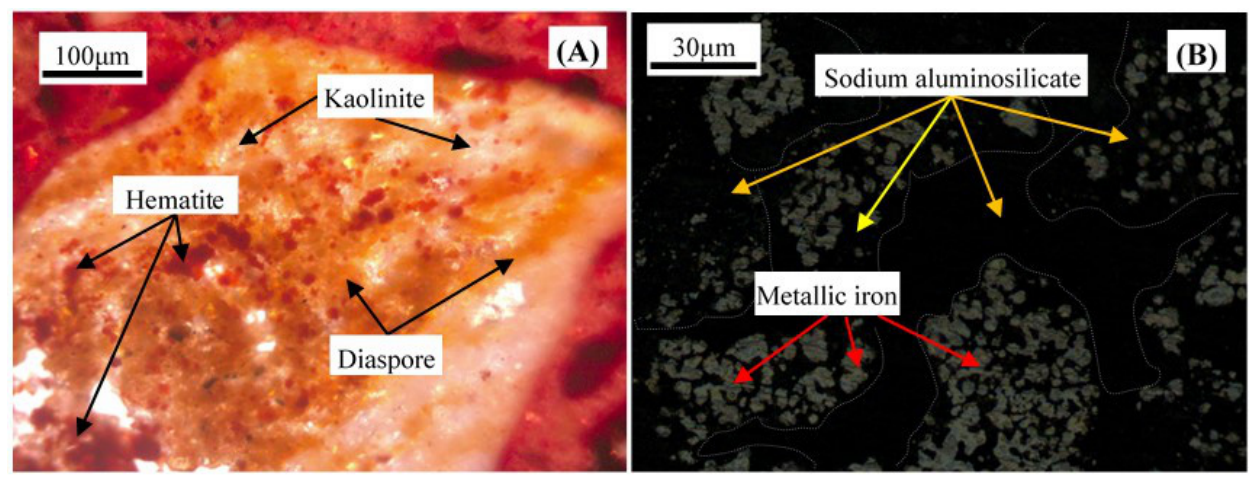

Figure 7. Microstructures of iron-rich bauxite ore and reduced bauxite with sodium salts. (A) Iron-rich bauxite ore (transparent light); (B) Reduced sample (polarized light).

The above analysis indicates that it is more difficult to extract alumina using the Bayer process when the bauxite ore is directly digested with the occurrence of closed minerals. Besides, the digestion 
of diaspore, as the main aluminum-bearing mineral, is also limited at low temperatures. The strict digestion conditions such as a high temperature and high caustic ratio are required (Table 2).

For the non-magnetic material, the satisfactory separation of iron and aluminum-bearing minerals can be achieved via reduction roasting followed by magnetic separation. The independent phases diaoyudaoite and sodium aluminosilicate, obtained via the magnetic separation of reduced bauxite with sodium salts, are original alumina sources when the non-magnetic material is used as the Bayer digestion feed. The separation and transformation of aluminum-bearing minerals is in favor of the alumina digestion at low digestion temperatures (Table 2). On the other hand, the high content of $\mathrm{Na}_{2} \mathrm{O}$ in the non-magnetic material can be introduced into pregnant liquor during the digestion of diaoyudaoite and sodium aluminosilicate, and during the increase of caustic soda concentration and caustic ratio.

It should be pointed out that the actual digestion ratio of alumina is only $60 \%$ in spite of the high relative digestion ratio of alumina (up to $99.5 \%$ ). This is explained by the low A/S ratio of the feeds (only 2.77 and 2.39 for iron-rich bauxite ore and non-magnetic material, respectively). It can be inferred that the actual digestion ratio of alumina is improved significantly when the raw material bauxite ore has a high A/S ratio. In other words, the technology proposed in this study reveals a new direction for exploitation of iron-rich diasporic bauxite ore.

\section{Conclusions}

The digestion of alumina from non-magnetic material obtained after reductive roasting of an iron-rich diasporic bauxite ore with sodium salts followed by magnetic separation was investigated in the present study. The digestion temperature significantly decreases from $280{ }^{\circ} \mathrm{C}$ to $240{ }^{\circ} \mathrm{C}$ and the yield of red mud also reduces from $78.19 \%$ to $56.59 \%$ in the Bayer process using a non-magnetic material as the feed compared with the direct digestion of alumina from the iron-rich bauxite ore. When the optimum conditions are a digestion temperature of $240{ }^{\circ} \mathrm{C}$ and a time of $60 \mathrm{~min}$, a caustic soda concentration of $240 \mathrm{~g} / \mathrm{L}$, a caustic ratio of 3.0 and a lime dosage of $4.0 \%$, the relative digestion ratio of alumina in the non-magnetic material is $99.58 \%$. It indicates that the alumina in the non-magnetic material can be extracted almost completely. During the reductive roasting, the sodium salts react with aluminum- and silicon-bearing minerals, destroying the original structures of the minerals in the bauxite ore. Meanwhile, the generation of diaoyudaoite and sodium aluminosilicate in reductive roasting is further beneficial to alumina extraction at a relatively low digestion temperature, contributing to satisfactory alumina digestion.

Acknowledgments: The authors wish to express their thanks to the National Science Foundation of China (Nos. 51234008 and 51174230) for the financial support. This work was also financially supported by Co-Innovation Center for Clean and Efficient Utilization of Strategic Metal Mineral Resources.

Author Contributions: Guanghui Li and Tao Jiang conceived and designed the experiments; Jun Luo and Zhuoxuan Li performed the experiments, analyzed the data and wrote the paper; Zhiwei Peng and Yuanbo Zhang supervised experimental work and reviewed the manuscript.

Conflicts of Interest: The authors declare no conflict of interest.

\section{References}

1. Power, G.; Gräfe, M.; Klauber, C. Bauxite residue issues: I. Current management, disposal and storage practices. Hydrometallurgy 2011, 108, 33-45. [CrossRef]

2. Klauber, C.; Gräfe, M.; Power, G. Bauxite residue issues: II. Options for residue utilization. Hydrometallurgy 2011, 108, 11-32. [CrossRef]

3. Kahn, H.; Tassinari, M.M.L.; Ratti, G. Characterization of bauxite fines aiming to minimize their iron content. Miner. Eng. 2003, 16, 1313-1315. [CrossRef]

4. Papassiopi, N.; Vaxevanidou, K.; Paspaliaris, I. Effectiveness of iron reducing bacteria for the removal of iron from bauxite ores. Miner. Eng. 2010, 23, 25-31. [CrossRef]

5. Pickles, C.A.; Lu, T.; Chambers, B.; Forster, J. A study of reduction and magnetic separation of iron from high iron bauxite ore. Can. Metall. Q. 2012, 51, 424-433. [CrossRef] 
6. U.S. Geological Survey. Mineral Commodity Summaries 2016; U.S. Geological Survey: Reston, VA, USA, 2016; pp. 32-33.

7. Liu, W.; Yang, J.; Xiao, B. Review on treatment and utilization of bauxite residues in China. Int. J. Miner. Process. 2009, 93, 220-231. [CrossRef]

8. Gräfe, M.; Power, G.; Klauber, C. Bauxite residue issues: III. Alkalinity and associated chemistry. Hydrometallurgy 2011, 108, 60-79. [CrossRef]

9. Li, G.; Liu, M.; Rao, M.; Jiang, T.; Zhuang, J.; Zhang, Y. Stepwise extraction of valuable components from red mud based on reductive roasting with sodium salts. J. Hazard. Mater. 2014, 280, 774-780. [CrossRef] [PubMed]

10. Kinnarinen, T.; Lubieniecki, B.; Holliday, L.; Helsto, J.J.; Häkkinen, A. Recovery of sodium from bauxite residue by pressure filtration and cake washing. Int. J. Miner. Process. 2015, 141, 20-26. [CrossRef]

11. Rao, R.B.; Besra, L.; Reddy, B.R.; Banerjee, G.N. The effect of pretreatment on magnetic separation of ferruginous minerals in bauxite. Magn. Electr. Sep. 1997, 8, 115-123. [CrossRef]

12. Halmann, M.; Epsteinb, M.; Steinfeld, A. Vacuum carbothermic reduction of bauxite components: A thermodynamic study. Min. Process. Extr. Metall. Rev. 2011, 33, 190-203. [CrossRef]

13. Li, Z.; Jin, J.; Wang, Y.; Wu, Y. Study on preparation of iron powder and nano-carbon black by reaction process of high-iron bauxite and natural gas. Integr. Ferroelectr. 2015, 160, 160-168. [CrossRef]

14. Peng, Z.; Hwang, J.Y. Microwave-assisted metallurgy. Int. Mater. Rev. 2015, 60, 30-63. [CrossRef]

15. Anand, P.; Modak, J.M.; Natarajan, K.A. Biobeneficiation of bauxite using Bacillus polymyxa: Calcium and iron removal. Int. J. Miner. Process. 1996, 48, 51-60. [CrossRef]

16. Bai, S.; Wen, S.; Liu, D.; Zhang, W.; Xian, Y. Catalyzing carbothermic reduction of siderite ore with high content of phosphorus by adding sodium carbonate. ISIJ Int. 2011, 51, 1601-1607. [CrossRef]

17. Jiang, M.; Sun, T.; Liu, Z.; Kou, J.; Liu, N.; Zhang, S. Mechanism of sodium sulfate in promoting selective reduction of nickel laterite ore during reduction roasting process. Int. J. Miner. Process. 2013, 123, 32-38. [CrossRef]

18. Li, G.; Jiang, T.; Liu, M.; Zhou, T.; Fan, X.; Qiu, G. Beneficiation of high-aluminium-content hematite ore by soda ash roasting. Min. Process. Extr. Metall. Rev. 2010, 31, 150-164. [CrossRef]

19. Li, G.; Shi, T.; Rao, M.; Jiang, T.; Zhang, Y. Beneficiation of nickeliferous laterite by reduction roasting in the presence of sodium sulfate. Miner. Eng. 2012, 32, 19-26. [CrossRef]

20. Li, G.; Zhang, S.; Rao, M.; Zhang, Y.; Jiang, T. Effects of sodium salts on reduction roasting and Fe-P separation of high-phosphorus oolitic hematite ore. Int. J. Miner. Process. 2013, 124, 26-34. [CrossRef]

21. Tang, H.; Sun, W.; Hu, Y.; Han, H. Comprehensive recovery of the components of ferritungstite base on reductive roasting with mixed sodium salts, water leaching and magnetic separation. Miner. Eng. 2016, 86, 34-42. [CrossRef]

22. Jiang, T.; Li, Z.; Yang, L.; Li, G.; Zhang, Y.; Zeng, J. Recovery of iron from hematite-rich diasporic-type bauxite ore. In The Minerals, Metals \& Materials Society (TMS), Proceedings of the 6th International Symposium on High-Temperature Metallurgical Processing, Orlando, FL, USA, 15-19 March 2015; John Wiley \& Sons, Inc.: Hoboken, NJ, USA; pp. 1-10.

23. Borra, C.R.; Blanpain, B.; Pontikes, Y.; Binnemans, K.; Gerven, T.V. Recovery of rare earths and other valuable metals from bauxite residue (red mud): A review. J. Sustain. Metall. 2016. [CrossRef]

24. Liu, W.; Sun, S.; Zhang, L.; Jahanshahi, S.; Yang, J. Experimental and simulative study on phase transformation in Bayer red mud soda-lime roasting system and recovery of $\mathrm{Al}$, $\mathrm{Na}$ and Fe. Miner. Eng. 2012, 39, 213-218. [CrossRef]

25. Kaußen, F.M.; Friedrich, B. Methods for alkaline recovery of aluminum from bauxite residue. J. Sustain. Metall. 2016. [CrossRef]

26. Qiu, G.; Jiang, T.; Li, G.; Fan, X.; Huang, Z. Activation and removal of silicon in kaolinite by thermochemical process. Scand. J. Metall. 2004, 33, 121-128. [CrossRef]

27. Li, J.; van Heiningen, A.R.P. Kinetics of sodium sulfate reduction in the solid state by carbon monoxide. Chem. Eng. Sci. 1988, 43, 2079-2085. [CrossRef]

28. Guo, Q.; Qu, J.; Han, B.; Wei, G.; Zhang, P.; Qi, T. Dechromization and dealumination kinetics in process of $\mathrm{Na}_{2} \mathrm{CO}_{3}$-roasting pretreatment of laterite ores. Trans. Nonferr. Met. Soc. China 2014, 24, 3979-3986. [CrossRef]

(C) 2016 by the authors; licensee MDPI, Basel, Switzerland. This article is an open access article distributed under the terms and conditions of the Creative Commons Attribution (CC-BY) license (http:/ / creativecommons.org/licenses/by/4.0/). 